\title{
The Problem of Democracy against the Background of the Theory of Origin and Authority in the Social Doctrine of the Church Fathers and St. Thomas Aquinas*
}

\section{Introduction}

In order to understand the concept of origin and authority as well as the problem of democracy in a tradition that took shape in Antiquity and the Christian Middle Ages, becoming a permanent part of the general social doctrine of the Church, one should refer to the Holy Bible and works of the main representatives of the theological and philosophical thought of Christianity, namely, Saint Augustine and Saint Thomas Aquinas. One should also refer to the characteristics of political systems made by Aristotle in Politics.

At the same time, it is essential to understand the reasoning contained in the abovementioned sources without imposing any foreign conceptual categories that, despite being broadly described by contemporary philosophers, sociologists, political scientists, etc., turn out to be insufficient for expressing the thinking contained in the works of previous eras.

Typically, a serious obstacle in noticing the occurrence of certain issues, let alone their correct analysis, is the lack of knowledge of the concepts and methods of philosophy and theology that were used in the Christian Antiquity and later in the Middle Ages. Hence, historians are missing the proper sense of many statements that testify to the existence of at least theoretical problems that are nowadays commonly perceived as the discovery of modern thinkers. This obviously results in an incomplete and often thoroughly misconstrued assessment of the reasons followed by secular rulers and high officials of the 
Church, when they engaged in political disputes of their time, to recall the most well-known examples: the dispute between Pope Gregory VII and King Henry IV and the conflict between King Bolesław the Bold and Bishop Stanisław of Szczepanów that ended tragically, tension between the Church and the nation and secular authority in England after being conquered by William, forcing John the Lackland to issue The Great Charter of the Liberties (1215).

This article aims primarily at showing the theoretical background of decisions as well as political and social activities undertaken in late Antiquity and the Middle Ages. Although it was not widely known in those days, it pervaded into the culture in which the Christian religion was ubiquitous, and no-one dared to openly question its position. From this perspective, it can be said that the appearance of two great philosophical and theological syntheses of Saint Augustine and Saint Thomas Aquinas was not as much an efficient cause as a result and evidence of the changes in culture that Christianity made in the human mind. This, however, does not mean that the explicit denunciation of certain theses does not shape the views of future generations. On the contrary, it seems that modern political thinking has gained some originality, emancipating itself from the general context of classical philosophy and Christian theology. Let us refer to the abovementioned sources without touching on the issues of this emancipation, which, according to the author, contributed to the detachment of theory and political practice from its natural goal, which is the good of human society, without excluding anyone.

\section{The Issue of Authority in the Old and New Testament}

The Old Testament emphasizes that all authority originates from God. According to the descriptions of the Old Testament contained in historical books, rulers of the chosen people are subject to the special protection of God (e.g. the throne of David). Here, we can also find cases of God's precepts directed to pagan rulers (Jonah in Nineveh; see J 1:1-2.3:1-10). At the same time, the history of the chosen people described in the Old Testament shows that legitimate authority is not limited in its form to royalty; these descriptions also include Patriarchs and Judges ${ }^{1}$.

A significant addition to the understanding of the essence of authority can be found in the New Testament, where it is generally understood as ministry (Mt 10:24-28, Mk 10:41-45, Lk 22:25ff). As something natural, inscribed in created 
reality, and considering that God, the Creator exercises providential rule over its creation, authority does not mean a voluntary activity, but takes into account the well-being of all fellow men. Furthermore, Christ is shown as a King exercising authority, yet in a different way than the rulers of this world, a King who, due to his human nature, is a humble and submissive subject. He accepts political power, which is manifested by obedience to state laws, for example in the doctrine of rendering to Caesar the things that are Caesar's (Mt 22:15-21)2. Saint Paul describes it even clearer in the following words: "Let everyone be subject to the governing authorities, for there is no authority except that which God has established. The authorities that exist have been established by God. Consequently, whoever rebels against the authority is rebelling against what God has instituted, and those who do so will bring judgment on themselves. For rulers hold no terror for those who do right, but for those who do wrong. Do you want to be free from fear of the one in authority? Then do what is right and you will be commended. For the one in authority is God's servant for your good. But if you do wrong, be afraid, for rulers do not bear the sword for no reason. They are God's servants, agents of wrath to bring punishment on the wrongdoer. Therefore, it is necessary to submit to the authorities, not only because of possible punishment but also as a matter of conscience. This is also why you pay taxes, for the authorities are God's servants, who give their full time to governing. Give to everyone what you owe them: If you owe taxes, pay taxes; if revenue, then revenue; if respect, then respect; if honour, then honour." (Rom 13:1-7).

This text does not serve as an acceptance of any particular authority that may be unjust, but as a reference to the very essence of social authority. It assumes that all authority comes from God, the Creator and is inscribed in the plans of Providence and the rule of God over the world, which is overridden by political authority that normalizes social life. As a result of this reality, authority as such demands respect in one's conscience. The last sentences of the cited text point to the objective of authority that is justice which intends to give each what he/she deserves. It is therefore considered in the perspective of faith and morality and it is generally shown as a moral reality that revaluates itself on the social level'.

It seems that neither the Old Testament nor the New Testament covered the issue of democracy. However, the general principles of authority and the interpretation of its origin contained therein obviously refer also to this particular form of authority.

Ibid., 180.

Cf. M. Krapiec, O ludzka polityke, Warsaw 1996, 110-115. 


\section{The Problem of Authority among the Church Fathers}

The primacy of justice and the common good when exercising authority was strongly emphasized by some of the Church Fathers. An example here can be the attitude of Saint John Chrysostom (347-407), who ordered the church door be locked before Empress Eudoxia after she had appropriated a vineyard that belonged to a widow. On the other hand, Saint Gregory the Great (Pope Gregory I) (540-604) punished himself for failing to take care of his subjects after a beggar was found dead in Rome that was under his authority.

The problem of authority was also the subject of Saint Augustine's (354-430) scientific research, becoming one of the central issues of his social philosophy ${ }^{4}$. Augustine was by no means a supporter of democracy and probably never even compared various system types. Nonetheless, he recognized the social dimension of human functioning and therefore he demanded that all Christians engage in the activities of state institutions that served the community ${ }^{5}$. The Bishop of Hippo maintains the classic view that the source of this reality, that is authority, is God and that the authority itself is good as it is primarily the domain of God'.

It goes without saying that God has no faults, being the Fullness of Good, and he exercises authority over his creation. He also allows some creatures to participate in the rule. In the works of Saint Augustine, men who have been created in the image and likeness of the Creator and are rational subjects endowed with freedom of choice and appear as members of God's rule over the world (cf. Gen 1:26ff). This perspective shows that every human being has their own particular dignity. If one used it to interpret the social thought of the Bishop of Hippo and the whole Christian tradition, it would have to be concluded that in some way it makes room for the wide participation of citizens in public life, despite the fact that in some historical conditions of Christian antiquity and the Middle Ages, there were no democracies. It seems that Augustine's words should be understood in the following spirit: "(...) we say that they [ed. - the

4 They are briefly discussed by Cz. Strzeszewski, Katolicka nauka społeczna, op. cit., pp. 185-186 and id., Filozofia społeczna A., in: Powszechna Encyklopedia Filozofii, vol. 1, Lublin 2000, 409-410; and W. Kornatowski, Introduction, IV, in: Saint Augustine, O państwie Bożym, Warsaw 1977. More on the social philosophy of Saint Augustine: E. Gilson, Wprowadzenie do filozofii sw. Augustyna, Warsaw 1953, 227-244; W. Kornatowski, Społeczno-polityczna myśl św. Augustyna, Warsaw 1965.

5 De civitate Dei, XIX, 5.

6 Ibid., V, 19. 
rulers] are happy if they rule justly; if they are not lifted up amid the praises (...), but remember that they are men; if they make their power the handmaid of His majesty by using it for the greatest possible extension of His worship; if they fear, love, worship God; if more than their own they love that kingdom in which they are not afraid to have partners."

Subjects are not treated as slaves but as "partners" in the political structure, and the ruler is equal to them in humanity, having specific authority.

St. Augustine and the other Church Fathers did not deal directly with the problem of choosing the most appropriate system, hence separate considerations of the subjects' participation in the rule over the state did not appear in their works even theoretically. St. Augustine was interested in the reasons for the existence of authority as such. Thus, on the one hand, he pointed to God as the one to whom authority belongs in an absolute way and who establishes every other authority, and on the other hand he indicated the objective of all authorities, that is the objective good.

For human societies, order and peace are so good and objective allowing all members of the state community to grow in general prosperity, while in the Christian perspective, justice itself is not enough to achieve these goods. There is a need to implement the rules of social conduct resulting from the commandment to love God and one's neighbour. State authority is supposed to take care of its subjects, it is a social service, its orders should originate "not from a love of power, but from a sense of the duty they owe to others - not because they are proud of authority, but because they love mercy." Those who are the object of care should be obedient, because the initiation of quarrels and rebellion leads to anarchy, in which the good of the whole community is lost ${ }^{8}$.

As can be seen, Saint Augustine does not perceive authority as subordinating the good of subjects to the state interest, or the emperor as an absolute in which the state interest is realized. The ruler is understood as the servant of all, and privileges resulting from the rule are objectively justified in social service, in the service of the common good. The ruler is also a member of the directed community, he is also a man and he has no right as a man to rise above others.

While formulating the principles of authority, the Bishop of Hippo did not describe a utopian place that does not exist, but pointed to the foundation of political institutions. He knew perfectly well that real forms of rule and people standing behind them do not always fulfil their duties, abusing privileges. He

Ibid., V, 24.

Ibid., XIX, 14; cf. ibid., XIX, 15.16 and Confessiones, III, 7, 13. 
also drew attention to unjust state laws, which require officials to perform unlawful acts ${ }^{9}$. Despite all reservations, guided by the principle of a greater good, that is social peace, he urged all people to subordinate to legal authority, even if it is not the best, patiently enduring its requirements as a merit for the Kingdom of $\mathrm{God}^{10}$. Patience cannot explain tolerance for what opposes a true religion, beguiling people into ungodliness and wickedness. Authority, originating from God, even uthority assigned to the objectives of the "earthly state," should lead subjects to God through the establishment of fair rights and building social peace. If, however, the opening leads away from obedience to God, it opposes the very essence of authority and it should inevitably face resistance of Christians. Today, that resistance, as pointed out by Augustine, would be called passive resistance. It does not call for an armed uprising, but rather for abandonment of wrong laws and making peaceful efforts to change them. It also brings forward martyrs who, with their radical testimonies for the Christian religion, "confessing, professing, and proclaiming it, by enduring all things for it with fidelity and fortitude, and by dying for it with pious calmness, put to shame the law by which that religion was prohibited, and caused its revocation."11

\section{The Issue of Authority from the Perspective of Saint Thomas Aquinas}

The aforementioned views of Saint Augustine gained a permanent place in the social doctrine of the Church and the philosophy imbued with Christian spirit, similarly to the theory of Saint Thomas Aquinas (1224/5-1274) which is the most important achievement and a special testimony to the political thought of the Middle Ages ${ }^{12}$. The Doctor of the Church, also known as Doctor Angelicus, supplemented the basis of this doctrine with concepts derived from the texts

9 In De civitate Dei, XIX, 6 Augustine gives an example of the senselessness and wickedness of torture provided for by law in order to verify testimonies. He points out that torture is applied even in the case of those people who were not ascertained to commit a crime, assuming that they will admit guilt as a result of the experienced pain. Meanwhile, it is often the case that innocent men are tortured and make false confessions to free themselves from pain, and stronger culprits can at times avoid a punishment because they endure the torture without confessing.

$10 \quad$ De civitate Dei, V, 17.

11 Ibid., VIII, 19; cf. ibid., XIX, 17 and II, 19. Cf. Cz. Strzeszewski, op. cit., $185 f$.

12 An excellent and accessible elaboration of the discussed issues can be found in E. Gilson, Tomizm, Warsaw 1998, 350-380. See also the general historical and multifaceted description of the problem of authority in M. Gogacz, Mądrość buduje państwo, Niepokalanów 1993, 181-191. 
of Aristotle of Stagira (384-322). It was a new element fitting a thousand-yearold Christian tradition, as people in earlier centuries probably did not trust the philosopher's thoughts, regardless of whether he explained the matters of God or humans. Therefore, his social theory was not used.

The works of the Stagirite, especially the Politics, introduced the concept of a tri-division of all possible state systems, along with the notions of republic and democracy into the intellectual culture of the Middle Ages. Aristotle divided political systems into those which were ruled by a unit (1); those with a small group of rulers, for example several people (2); and those ruled by the general public (3). Each of the mentioned types can take a just form the one in which the authority cares for the common good of its subjects, or are a twisted form in which the authority cares only for its own private interest. If an individual rules, we have either monarchy or tyranny; if a small group rules: aristocracy or oligarchy; if the general public rules: republic (politeia) or democracy ${ }^{13}$.

The word "democracy" in the terminology of Aristotle, and later Saint Thomas, means a degraded system. Doctor Angelicus adds that this is also a form of tyranny, in which the poor majority oppress the rich minority, staying in a symbiotic relationship. Democracy viewed in this light has more similarities with what we observed in the so-called "real socialism" than with what we want to call a democratic system. In the terminology of Aristotle and Thomas, just rule, which is nowadays associated with the notion of true democracy that cares for the common good of all citizens, not only the ruling class, is called "politeia" or "republic" ("Commonwealth") ${ }^{14}$. In the $20^{\text {th }}$ century, Pius XII pointed to this form of authority, defining it as a democracy of self-consciousness and aspirations of a nation whose members are aware of their national identity, their rights and duties and their dignity as human beings. He opposed such a democracy with the so-called "mass democracy" which is characterized by a lack of awareness of the purpose and therefore it is susceptible to all kinds of manipulations ${ }^{15}$.

Therefore, as can be seen, the republican system or the system of healthy democracy requires a high level of awareness of all citizens, otherwise it turns into a tyranny of the majority. Saint Thomas was aware of this fact and that is why he chose monarchy as the best and least risky system. Even then, when it turns into tyranny, an individual tyrant is unable to harm more of his subjects than the leading group or majority of the society. In addition, only a few

Aristotle, Politics, III, 4.5.

Sancti Thomae de Aquino, De regno ad regem Cypri, I, 1-2.

AAS 37 (1945), 10-23. 
individuals, as stated by Aquinas, are characterized by real virtue, so it is difficult to expect a group of people to keep a high moral level and rule for the good of the whole community ${ }^{16}$.

St. Thomas knew the history of the Jewish nation, Greece, Rome and the history of Christianity, and understood that specific social factors determine the formation of such a system in a given time and place. He also knew that artificial interference in the historical processes which he considered in the context of Divine Providence that sometimes permit human errors, may be unlikely to succeed in the existing situation, even though the intervention is aimed at establishing a good systemic form. For this reason, he did not recommend persistent striving to establish monarchy at all times and instances. Political activity should be therefore, according to him, aimed at avoiding tyranny in all its forms: one-man rule, oligarchy or degraded democracy ${ }^{17}$.

Although in general Doctor Angelicus opposed strength solutions believing that they destroyed the natural order of societies that require authority (that is why it is proclaimed to this very day that it originates from God), he allowed repudiation of allegiance to authority that turned into tyranny. He believed that "if a community has the right to make a king for itself, it is not unjust for them to overthrow or restrict him when he abuses royal authority in a tyrannous way." Aquinas states that the removal of a tyrant is an act of justice, even if the community previously promised their loyalty to him. The tyrant himself gives up his duties of exercising legitimate authority that originate only from $\mathrm{God}^{18}$.

It should be noted that in this approach there is no contradiction between the origin of authority from God and the choice or removal of the ruler by the community. Authority comes from God as a natural factor that organizes the society. In this respect, there is no organized community, and thus no political community, without assigning authority. In the second case, it regards a particular authority that a man has the right and the duty to choose, as he was chosen by God to be the world's host (see Gen 1:26-28). He must not destroy the wealth of nature entrusted to him, and he must not destroy other human beings, for example by tyrannizing them or by destroying the social order which, after all, results from natural relations occurring between people. Freedom in the use of authority (its abuse) as well as the introduction of anarchy in social life (lowering the influence of authority), destroy the right proportions in relations forming the order of the political community. According to Saint Thomas and

16 Sancti Thomae de Aquino, De regno ad regem Cypri, I, 4-5.

17 Ibid., I, 7.

18 Ibid. Quotation in: J. Salija, Dzieła wybrane, Poznań 1984. 
Saint Augustine, the influence of a human being is to direct the authority given to him by the Creator, giving the right to decide and to make decisions, is rooted in the rational and free nature of human beings. This influence cannot, however, destroy the very nature of authority if it is not to turn against men ${ }^{19}$.

The views of Saint Thomas do not legitimize absolute monarchy. The most surprising concept of monarchy, which he presents in his Summa Theologiae, is not a monarchy in the present conceptual categories: "Two points are to be observed concerning the right ordering of rulers in a state or nation. One is that all should take some share in the government: for this form of constitution ensures peace among the people (...). The other point is to be observed in respect of the kinds of government, or the different ways in which the constitutions are established. (...) Accordingly, the best form of government is in a state or kingdom, where one is given the power to preside over all; while under him are others having governing powers: and yet a government of this kind is shared by all, both because all are eligible to govern, and because the rules are chosen by all. For this is the best form of polity, being partly kingdom, since there is one at the head of all; partly aristocracy, in so far as a number of persons are set in authority; partly democracy, i.e. government by the people, in so far as the rulers can be chosen from the people, and the people have the right to choose their rulers." 20

\section{Conclusion}

The modern social doctrine of the Catholic Church supports all of the abovementioned views with the exception that it treats some of its elements as the so-called "signs of the times" in which the creators of these views lived and wrote. Therefore, we cannot say that they became somehow time-barred. They have entered the tradition of the social doctrine of the Church. Similarly, one cannot reasonably claim that the basic theses of the socio-political theories of Saint Augustine or Saint Thomas Aquinas are obsolete in philosophical terms. At the most, one can disagree with them or try to correct them. Nevertheless, it seems that there are no better analyses of the nature of authority and its origin from God. 
Considering these issues from the perspective of historical applications of the theories, especially the one coined by St. Thomas, it is impossible not to notice the significant analogies of the reflections of Doctor Angelicus and the idea of a "nobles' democracy" implemented in the First Polish Republic three hundred years later. It is also difficult to believe that after the creation of the scientific community of the Jagiellonian University in the fifteenth century, they did not affect the minds of Polish politicians at a time when the foundations of this democracy were formed. Moreover, it seems that these considerations were widely applied in the centuries-old process of crystallizing other modern and contemporary democratic system. 